\title{
Metyrapone Delays Surfactant and Antioxidant Enzyme Maturation in Developing Rat Lung
}

\author{
ILENE R. S. SOSENKO, PAMELA L. LEWIS, AND LEE FRANK \\ Pulmonary Research Laboratories, Calvin and Flavia Oak Asthma Research and Treatment Facility, \\ Department of Medicine and Division of Neonatology, Department of Pediatrics, University of Miami School of \\ Medicine, Miami, Florida 33136
}

\begin{abstract}
The surfactant system and the antioxidant enzyme system of the fetal lung have chronologically similar developmental patterns and both can be accelerated by the administration of exogenous glucocorticoids. To test whether the antioxidant enzyme system, like the surfactant system, is regulated, at least in part, by endogenous glucocorticoids, we injected pregnant rats for 3 days prior to delivery with metyrapone, an adrenal 11- $\beta$ hydroxylase inhibitor which crosses the placenta and blocks endogenous glucocorticoid synthesis, or saline. Metyrapone offspring had significantly decreased lung tissue disaturated phosphatidylcholine and disaturated phosphatidylcholine/total phospholipids $(p<0.05)$ compared to controls at days 21 and 22 of gestation. Activities of the antioxidant enzymes superoxide dismutase, catalase, and glutathione peroxidase were similarly significantly reduced $(p<0.01)$ in the lungs of metyrapone offspring at both gestational days studied. One day premature metyrapone pups demonstrated poorer survival than control pups from 25 min after delivery $(44 \%$ survival versus $83 \%, p<0.05)$ to $90 \mathrm{~min}(6 \%$ survival versus $78 \%, p<0.01)$. These findings of delayed maturation of the surfactant and antioxidant enzyme systems following adrenal glucocorticoid blockade suggest that both systems are regulated, at least in part, by an endogenous glucocorticoid mechanism. (Pediatr Res 20: 672-675, 1986)
\end{abstract}

\[ \text { Abbreviations } \]
DSPC, disaturated phosphatidylcholine
TPL, total phospholipids
AOE, antioxidant enzymes
SOD, superoxide dismutase
CAT, catalase
GP, glutathione peroxidase

The developmental patterns of the surfactant system and the antioxidant enzyme system of the fetal lung are chronologically similar, with both systems demonstrating marked increases during the final $10-15 \%$ of gestation in the several species studied (1-3). Both systems are important in the neonatal adaptation to independent respiration in the relatively oxygen-rich ex utero

Received December 16, 1985; accepted March 11, 1986

Address all correspondence to Ilene R. S. Sosenko, M.D., Pulmonary Research R120, University of Miami School of Medicine, P.O. Box 016960, Miami, FL 33101

This work was supported by funds from the American Lung Association, Basil O'Connor Research Grant 5-540, MOD, NHLBI Grants HL07283 and HL26029; Research Career Development Award HL01230 (L.F.); and a grant from Innovative Research of American, Rockville, MD. environment. While the surfactant system provides reduction in alveolar surface tension and prevents alveolar collapse at end expiration, the antioxidant enzyme system of the lung prevents cell injury from reactive species of oxygen which are produced under normoxic and hyperoxic conditions (4-6). Multiple lines of evidence indicate that surfactant development is regulated, in part, by endogenous glucocorticoids: elevation of plasma glucocorticoid levels prior to the increase in surfactant (7), the presence of and increase in glucocorticoid receptors in fetal lung prior to elevation in surfactant $(8-10)$, and delays in surfactant maturation following interference with glucocorticoid production either biochemically (i.e. with metyrapone) or surgically (i.e. by fetal decapitation or hypophysectomy) (11-15).

It has recently been demonstrated that the maturation of the pulmonary AOE, namely superoxide dismutase, catalase, and glutathione peroxidase, as well as surfactant (as measured by lung tissue, DSPC) can be accelerated in the rat with the prenatal administration of exogenous glucocorticoid (16). We undertook the present study to determine whether the antioxidant enzymes, like surfactant, might be regulated, in part, by an endogenous glucocorticoid mechanism. We have produced adrenal blockade in fetal rats with metyrapone, an adrenal $11-\beta$ steroid hydroxylase inhibitor, examined the maturation of the surfactant and antioxidant enzyme systems, and report herein a parallel supression of lung tissue DSPC and AOE in the late gestation fetal rat.

\section{MATERIALS AND METHODS}

Animals and Treatments. Adult Sprague-Dawley albino female rats $(\sim 250 \mathrm{~g})$ were bred by placing male and female together overnight, checking for sperm-positive vaginal smears the following morning, and considering the midpoint of the cohabitation period as the onset of pregnancy. The female rats with timed pregnancy were maintained on standard laboratory food and water ad libitum and were kept on a cycle of $12 \mathrm{~h}$ light/12 h darkness.

At 72,48 , and $24 \mathrm{~h}$ prior to premature delivery at 21 days or term delivery at 22 days gestation, pregnant rats were injected intraperitoneally twice daily with metyrapone (2 methyl-1-2-di3 pyridyl-1-propanone) (Sigma Chemical Co., St. Louis, MO), an adrenal 11- $\beta$ steroid hydroxylase inhibitor, $45 \mathrm{mg} / \mathrm{kg} / \mathrm{dose}$. A separate group received equivalent volumes of normal saline (diluent) injected at the above dosage schedule. Metyrapone rats, once injections were begun, were provided with normal saline and $5 \%$ dextrose in water (to prevent potential salt-wasting and hypoglycemia secondary to mineralocorticoid/glucocorticoid inhibition) in addition to regular drinking water and laboratory food.

Seventy-two h after the onset of injections, rat fetuses of 21 days gestational age were delivered by hysterotomy under pentobarbital anaesthesia. Newborn rats ( 22 days) were obtained after normal parturition, usually within $6 \mathrm{~h}$ of the beginning of 
delivery of the first pup. Body weights and lung weights were recorded.

Serum total corticosterone levels were assayed in random metyrapone-injected and control rats and their litters by radioimmunoassay kits (Radioassay Systems Labs, Carson, CA).

Lung biochemistry. Fetal or newborn lungs were perfused immediately in situ via the pulmonary artery using cold saline. The left atrial appendage was cut to facilitate drainage of the perfusate. The perfused lungs were removed, stripped of nonpulmonary tissue, and homogenized in $20-30 \times$ their weight of cold saline in a Brinkman polytron (high speed, $90 \mathrm{~s}$ ). For preterm or small newborns, two to four lungs were pooled to obtain adequate tissue for the assays.

Aliquots of the homogenate were subsequently analyzed for antioxidant enzyme activities using standard spectrophotometric assays for SOD (17), CAT (18), GP (19), and for DNA (20) and protein assay (21). Purified enzyme standards (SOD, CAT) and DNA standard were obtained from Sigma Chemical Co. and Boeringer Manheim Co., Indianapolis, IN (GP). Results of antioxidant enzyme analyses were expressed as units of enzyme activity per mg DNA as well as per mg protein and per $g$ lung weight.

Lipid extraction of lung homogenate aliquots was performed according to the method of Bligh and Dyer (22). The lipid extract, once it was dried under nitrogen, was frozen prior to phospholipid analysis. An aliquot of lipid extract was set aside for measurement of TPL. A second aliquot was assayed for DSPC using the procedure described by Mason et al. (23). After the DSPC was separated from the other phospholipids, the DSPC and TPL samples were assayed for inorganic phosphorus using the method of Morrison (24). A known quantity of ${ }^{14} \mathrm{C}$-dipalmitoyl-phosphatidylcholine (New England Nuclear, Boston, MA) was added prior to lipid extraction and aliquots counted at each step to estimate and correct for sequential losses. Lipids were expressed as $\mathrm{mg} / \mathrm{g}$ wet lung weight, per $\mathrm{mg}$ protein and as a ratio of $\mathrm{mg}$ DSPC/mg TPL.

Survival study. One day premature (day 21 of the normal 22 day gestation period) rat fetuses from metyrapone and control mothers were delivered by hysterotomy under ketamine:xylazine anaesthesia (Ketalar, $90 \mathrm{mg} / \mathrm{kg}$, Parke-Davis, Morris Plains, NJ; Rompun, $10 \mathrm{mg} / \mathrm{kg}$, Cutter Labs, Shawnee, KS). The pups were rapidly transferred to a specially constructed "isolette," consisting of a warmed $35^{\circ} \mathrm{C}$ covered cage assembly sitting atop a gently shaking water bath. The survival times of the two groups of premature pups were monitored at 10- to 15-min intervals.

Statistical analysis. Statistics were performed using Student's $t$ test and two-way analysis of variance (when comparing several litters of the same gestational age exposed to the same experimental conditions) (25). Corticosterone levels and survival data were compared using Fisher's nonparametric test (26).

\section{RESULTS}

General features of metyrapone-injected rats and their offspring. Approximately $50 \%$ of the metyrapone-injected pregnant rats appeared less active than saline-injected controls during the treatment period. However, fewer than $10 \%$ of metyraponeinjected rats died prior to sacrifice at 21 or 22 days, and there were no sigificant differences in miscarriages or intrauterine deaths.

Physical characteristics of metyrapone and control offspring are seen in Table 1. At 21 days of gestation, metyrapone offspring manifested significantly lower body weights and lung weights than control offspring; body and lung weights were not different between groups at day 22 (birth). Lung weight/body weight ratios were not different between groups at either gestational age studied. In addition, no differences in lung weight, body weight or lung/body weight were found in several litters examined at days 19 and 20 of gestation (not shown in Table 1). There were no significant differences in the ratio of wet lung weight/dry lung weight between the two groups.

Mean total serum corticosterone in metyrapone-injected dams was $134 \pm 19 \mathrm{ng} / \mathrm{ml}$ compared to $>400 \mathrm{ng} / \mathrm{ml}$ in control mother rats, mean $\pm \mathrm{SEM}, p<0.01$ (Fisher's); similarly, mean total serum corticosterone in offspring of metyrapone-injected rats was $296 \pm 50 \mathrm{ng} / \mathrm{ml}$ compared to $>400 \mathrm{ng} / \mathrm{ml}$ in control offspring, ( $n=10-14$ per group), $p=0.06$ (Fisher's).

Lung biochemistry. The developmental pattern of lung tissue DSPC and TPL (expressed as $\mathrm{mg} / \mathrm{g}$ lung) in metyrapone and control offspring at days 21 and 22 (birth) of gestation is seen in Figure 1. At both gestational days studied, offspring of metyrapone-injected rats had signficantly reduced lung DSPC content compared to controls ( $p<0.05$, two-way analysis of variance). TPL content was not significantly different between groups at either gestational age. The same relationships held true when DSPC and TPL were expressed per dry lung weight or per $\mathrm{mg}$ of protein rather than per $g$ wet weight of the lung. DSPC/TPL ratios were decreased in metyrapone offspring compared to controls at 21 days $(0.210 \pm 0.031$ versus $0.239 \pm 0.039)$ and 22 days $(0.233 \pm 0.030$ versus $0.287 \pm 0.058),(p<0.05$, two-way analysis of variance)

Figure 2 shows the developmental progression in antioxidant enzymes from day 21 to 22 in metyrapone-treated and control rat offspring. Mean activity units for all three antioxidant en-

Table 1. Physical characteristics of metyrapone and control offspring (mean $\pm S D$ )

\begin{tabular}{ccccc}
\hline $\begin{array}{c}\text { Gesta- } \\
\text { tional } \\
\text { age }\end{array}$ & Body wt & Lung wt & $\begin{array}{c}\text { Lung/body } \\
\text { wt }\end{array}$ \\
\hline & $\begin{array}{c}\text { Me- } \\
\text { tyra- } \\
\text { pone }\end{array}$ & $\begin{array}{c}4.29 \pm 0.86 \\
*\end{array}$ & $0.138 \pm 0.022$ & $3.28 \pm 0.50$ \\
21 & Control & $5.88 \pm 0.29$ & $0.164 \pm 0.017$ & $3.11 \pm 0.30$ \\
& $\begin{array}{c}\text { Me- } \\
\text { tyra- } \\
\text { pone }\end{array}$ & $5.81 \pm 1.26$ & $0.123 \pm 0.020$ & $2.14 \pm 0.20$ \\
& & & \\
22 & Control & $6.15 \pm 0.69$ & $0.126 \pm 0.021$ & $2.09 \pm 0.60$ \\
\hline
\end{tabular}

$* p<0.05, n=6$ litters metyrapone $/ 6$ litters control-21 days; $n=5$ litters metyrapone $/ 5$ litters control- -22 days.

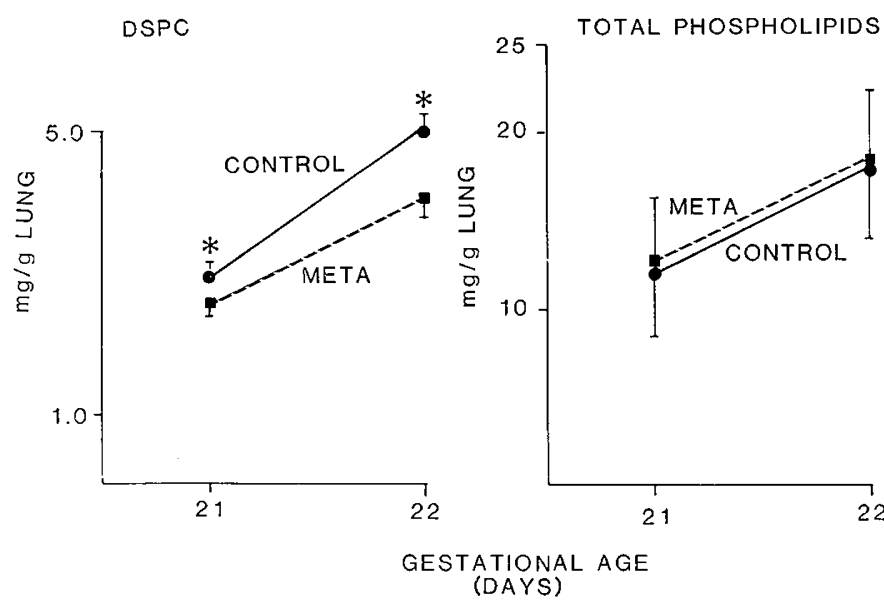

Fig. 1. Differences in lung DSPC and TPL content at 21 and 22 days of gestation in metyrapone and control offspring. Values represent mean \pm SEM. $^{*} p<0.05$ (two-way analysis of variance). $n, 21$ days-Metyrapone: six litters, 23 samples; control: six litters, 27 samples; 22 daysmetyrapone: five litters, 24 samples; control: five litters 17 samples. 


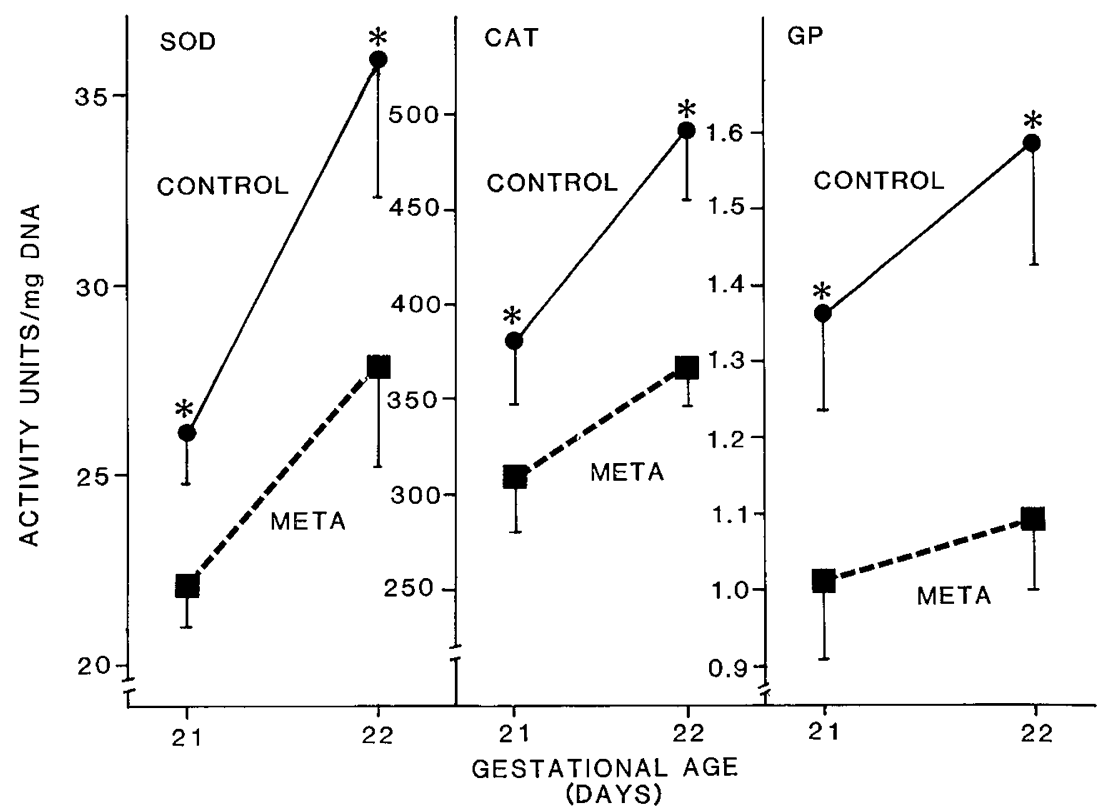

Fig. 2. Lung antioxidant enzyme activity levels of metyrapone and control fetuses at days 21 and 22 of gestation. Values represent mean \pm SEM. $* p<0.01$ (two-way analysis of variance). $n$, same as in legend to Figure 1 .

zymes (SOD, CAT, and GP) were significantly decreased in metyrapone offspring at days 21 and 22 of gestation $(p<0.01$, two-way analysis of variance).

Survival study. Survival data of 1 day premature rats from metyrapone and control mothers are depicted in Figure 3. Prematurely delivered metyrapone pups manifested significantly poorer survival rates, beginning at $25 \mathrm{~min}$ after delivery [7/16 (44\%) metyrapone pups surviving compared to $15 / 18(83 \%)$ of controls] and continuing to $90 \mathrm{~min}[1 / 16(6 \%)$ versus $14 / 18$ $(78 \%)]$, at which time the experiment was concluded.

\section{DISCUSSION}

Multiple studies have suggested that an endogenous glucocorticoid mechanism plays an important role in surfactant development. For example, a marked rise in fetal plasma cortisol occurs in sheep during the last days of fetal life, followed by a dramatic increase in fetal lung DSPC $(7,27)$. In the rat, corticosterone, rather than cortisol, is the main circulating adrenocorticosteroid (28), and peak values are reached on day 19 of gestation $(29,30)$. "Free" corticosterone levels also peak at days 19-20 and remain high until term (31). Since lung DSPC rises markedly between gestational days 20 and 22 in the rat (16), thereby closely following the reported corticosterone peak on day 19, the developmental pattern of rat and sheep appears similar. Our dosage schedule for metyrapone in the present study, with injections twice daily on days 18-20 with sacrifice on day 21 or injections on days 19-21 with sacrifice on day 22, was designed to eradicate or blunt this reported serum glucocorticoid peak.

In addition to the above temporal relationship between glucocorticoid peak and surfactant elevation, other lines of evidence-specifically receptor data $(8-10,32)$ and adrenocorticoid ablation or blocking studies (11-15) - provide additional support for endogenous glucocorticoid regulation of surfactant development.

Metyrapone works by inhibiting adrenal corticosteroid production through its inhibition of the 11- $\beta$ steroid hydroxylase enzyme (33). Goldman (34) reported a complete block in basal adrenal production of corticosterone in metyrapone-treated rats and provided indirect evidence of placental transfer of metyrapone by demonstrating congenital adrenogenital syndrome in the offspring of treated pregnant rats. Vidyasagar and Chernick

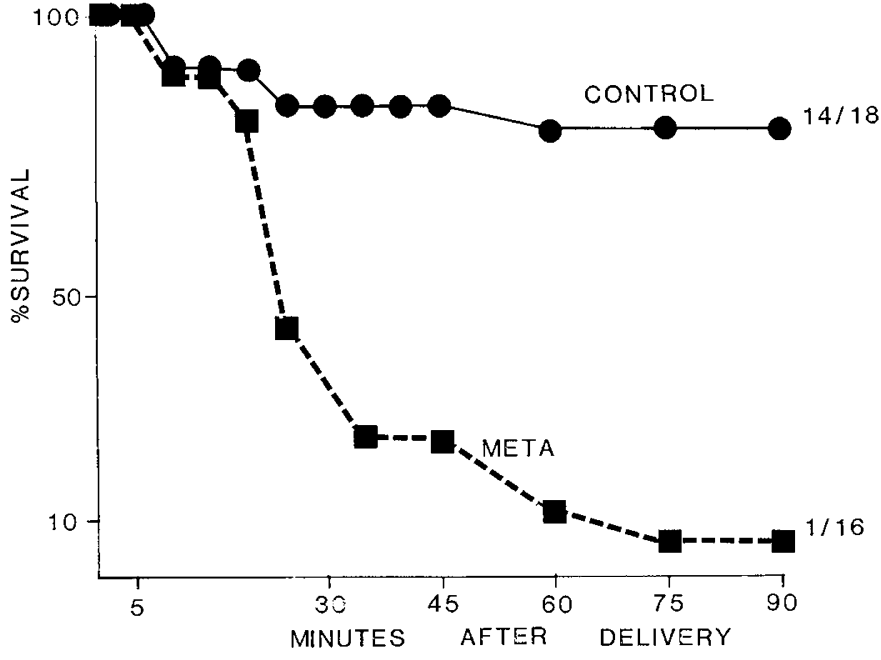

Fig. 3. Surival data of 1-day premature rat fetuses from metyraponeinjected and control mothers. From 25 to $90 \mathrm{~min}$ after delivery, survival differences are significant at $p<0.05$ or less (Fisher's test).

(35), utilizing measurements of fetal plasma metyrapone concentrations, provided direct evidence that metyrapone crosses the placenta in the rabbit. Our findings of reduction in fetal total plasma corticosterone levels following maternal metyrapone administration strongly suggests that metyrapone crosses the placenta in the rat as well. While we measured total corticosterone and did not measure "free" corticosterone levels per se, our observed interference with surfactant development (consistent with that of other investigators) would suggest that the active free hormone levels were affected by metyrapone treatment as well.

The significant decreases in lung tissue DSPC and DSPC/TPL we demonstrated during the final 2 days of gestation, following maternal metyrapone treatment in the rat are in agreement with earlier studies with this agent showing altered surfactant levels or function in rabbits (15), baboons (12), and guinea pigs (14). Our study, in addition, has demonstrated for the first time a parallel delay following metyrapone in a nonsurfactant-related biochemical system in fetal lung, the antioxidant enzyme system. 
The maturational pattern of the antioxidant enzyme system and the surfactant system in fetal lung is remarkably similar. Studies first reported in rats and rabbits $(1,3)$ and later extended to guinea pigs and hamsters demonstrate very marked elevations in superoxide dismutase, catalase, and glutathione peroxidase activities in addition to lung tissue DSPC during the final 10$15 \%$ of gestation (2). Because both the surfactant system and AOE system are important in the "preparation for birth" phenomenon, when the fetus makes the transition from the relatively hypoxic intrauterine environment to an oxygen-rich air breathing extrauterine environment, a possible commmonality in their regulatory mechanisms could be biologically advantageous. In fact, the surfactant and antioxidant enzyme systems are both responsive to exogenously administered glucocorticoids. We have recently reported that maternal treatment with dexamethasone in late gestation in the rat results in accelerated maturation of lung DSPC content and AOE activities in a parallel fashion (16). Our present study demonstrating delayed maturation of both systems following metyrapone provides evidence that an endogenous glucocorticoid mechanism may play a regulating role in pulmonary antioxidant enzyme as well as surfactant system development.

It should be noted that metyrapone is also a very effective inhibitor of cytochrome P-450, although at higher concentrations than is required to significantly inhibit $\beta$-hydroxylase activity (36). While P-450 inhibition has primarily been studied in liver, in vitro, of possible interest to the developing lung and the $\mathrm{AOE}$ is the recent finding that metyrapone treatment can inhibit arachidonic acid metabolism by microsomal P-450, decreasing P-450's lipoxygenase-like function and eicosanoid production (37). At this point it is only speculative but since AOE activity is known to respond to $\mathrm{O}_{2}$ radical and $\mathrm{H}_{2} \mathrm{O}_{2}$ substrate concentration by blocking the production of these $\mathrm{O}_{2}$ metabolites which are generated by oxidative systems such as P-450 (and lipoxygenase), metyrapone treatment could be influencing AOE levels by a nonglucocorticoid mechanism.

Both the surfactant system and antioxidant enzyme system may be crucial in enabling the newborn to adapt rapidly to independent respiration in a relatively oxygen-rich world. While surfactant acts to stabilize the alveoli as the newborn begins to breathe, SOD, CAT, and GP protect the lung from damage caused by oxygen-free radicals and other reactive oxygen metabolites produced in (lung) cells under oxidant conditions (4-6). Our metyrapone rat fetuses demonstrated dramatically poorer survival than control pups when delivered 1 day prematurely. Whether this decrease in survival is due to metyrapone's effect on surfactant, antioxidant enzymes, or both (or perhaps due to unrelated phenomena) has not been determined in this study. These biochemical results do suggest, however, that human infants with delayed surfactant development which may be related at least in part to low glucocorticoid levels, may have delayed development of their antioxidant enzyme system as well, and may demonstrate intolerance to high oxygen in addition to hyaline membrane disease if delivered too prematurely.

Acknowledgments. The authors thank Mrs. Ondina GarciaPons for preparation of the manuscript.

\section{REFERENCES}

1. Frank L, Groseclose EE 1984 Preparation for birth into an $\mathrm{O}_{2}$-rich environment: the antioxidant enzymes in the developing rabbit lung. Pediatr Res $18: 240-244$

2. Sosenko I, Frank L 1985 Preparation for birth of the fetal lung antioxidant enzymes in four species. Am Rev Respir Dis 131:A237

3. Tanswell KK, Freeman BA 1984 Pulmonary antioxidant enzyme maturation in fetal and neonatal rat lung. I. Developmental profiles. Pediatr Res 18:584586

4. Forman HJ, Fisher AB 1981 Antioxidant defenses. In: Gilbert DL (ed) Oxygen and Living Processes: An Interdisciplinary Approach. Springer-Verlag, New York, pp 235-249

5. King RK 1982 Pulmonary surfactant. J Appl Physiol 53:1-8

6. Mead JF, Wu G-S, Stein RA, Gelmont D, Sevanian A, Sohlberg E, McElhaney RN 1982 Mechanisms of protection against membrane peroxidation. In: Yagi K (ed) Lipid Peroxides in Biology and Medicine. Academic Press, New York, pp 161-178

7. Kitterman JA, Campos GA, Clements JA, Forster CS, Lee CH, Creasy RK 1981 Prepartum maturation of the lung: relation to cortisol. J Appl Physiol 51:384-390

8. Ballard PL, Ballard RA 1974 Cytoplasmic receptor for glucocorticoids in the lung of the human fetus and neonate. J Clin Invest 53:477-486

9. Giannopoulos G 1973 Glucocorticoid receptors in lung. I. Specific binding of glucocorticoids to cytoplasmic components of rabbit fetal lung. J Biol Chem 248:3876-3883

10. Giannopoulos G, Mulay S, Solomon S 1973 Glucocorticoid receptors in lung. II. Specific binding of glucocorticoids to nuclear components of rabbit fetal lung. J Biol Chem 248:5016-5023

11. Blackburn WR, Kelly JS, Dickman PS, Travers H, Lopata MA, Rhoades RA 1973 The role of the pituitary-adrenal-thyroid axes in lung differentiation. Lab Invest 28:352-360

12. Kling OR, Kotas RV 1975 Endocrine influences on pulmonary maturation and lecithin/sphingomyelin ratio in the fetal baboon. Am J Obstet Gynecol 121:664-668

13. Liggins G, Kitterman JA, Campos GA, Clements JA, Forster CS, Lee CH Creasy RK 1981 Pulmonary maturation in the hypophysectomized ovine fetus. Differential response to adrenocorticotropin and cortisol. J Dev Physiol $3: 1-14$

14. Nelson GH, Eguchi K, McPherson JM 1976 Effects of gestationl age, dexamethasone and metopirone on lecithin concentration in fetal lung tissue and amniotic fluid in rats and guinea pigs. Gynecol Invest 7:337-343

15. Vidyasagar D, Chernick V 1975 Effect of metopirone on the synthesis of lung surfactant in does and fetal rabbits. Biol Neonate 27:1-16

16. Frank L, Lewis PL, Sosenko IRS 1985 Dexamethasone stimulation of fetal rat lung antioxidant enzyme activity in parallel with surfactant stimulation. Pediatrics 75:569-574

17. McCord JM, Fridovich I 1969 Superoxide dismutase: an enzymic function for erythrocuprein (hemocuprein). J Biol Chem 244:6049-6055

18. Holmes RS, Masters CJ 1970 Epigenetic interconversion of the multiple forms of mouse liver catalase. FEBS Lett 11:45-48

19. Paglia DE, Valentine WN 1967 Studies on the quantitative and qualitative characterization of erythrocyte glutathione peroxidase. J Lab Clin Med 70:158-159

20. Richards GM 1974 Modifications of the diphenylamine reactions giving increased sensitivity and simplicity in the estimation of DNA. Anal Biochem 57:369-376

21. Schacterle RE, Pollack RL 1973 A simplified method for the quantitative assay of small amounts of protein in biological material. Anal Biochem 51:654655

22. Bligh EF, Dyer WJ 1959 A rapid method of total lipid extraction and purification. Can J Biochem Physiol 37:911-917

23. Mason RJ, Nellenbogen J, Clements JA 1976 Isolation of disaturated phosphatidylcholine with osmium tetroxide. J Lipid Res 17:281-284

24. Morrison WR 1964 A fast, simple and reliable method for the microdetermination of phosphorus in biological materials. Anal Biochem 11:218-224

25. Steel RGD, Torrie JH 1960 Principles and Procedures of Statistics. McGrawHill, New York, pp 67-98

26. Fisher RA 1970 Statistical Methods for Research Workers. Hafner Press, New York, pp 213-224

27. Basset JM, Thorburn GD 1969 Fetal plasma corticoids and the initiation of parturition in sheep. J Endocrinol 44:285-286

28. Malinowska KW, Hardy RN, Nathanielsz PW 1972 Plasma adrenocorticosteroid concentrations immediately after birth in the rat, rabbit and guinea pig. Experientia 28:1366-1367

29. Cohen A 1973 Plasma corticosterone concentration in the fetal rat. Horm Metab Res 5:66

30. Holt PG, Oliver IT 1968 Plasma corticosterone concentrations in the perinatal rat. Biochem J 108:338-341

31. Gewolb SH, Warshaw JB 1983 Free and total plasma corticosterone concentration in fetuses of normal and diabetic rats. Pediatr Res 17:132A

32. Murphy BEP, Diez d'Aux RC 1972 Steroid levels in the human fetus: cortisol and cortisone. J Clin Endocrinol Metab 35:678-683

33. Allen MJ, Bencze WI 1969 Chemistry and structure activity relationship of amphenone analogues. J Med Pharm Chem 1:395-406

34. Goldman AS 1967 Experimental model of congenital adrenal cortical hyperplasia produced in utero with an inhibitor of $11 \beta$ steroid hydroxylase. J Clin Endocrinol 27:1390-1394

35. Vidyasagar D, Chernick V 1972 Placental transfer of Metopirone. Biol Neonate 21:471-474

36. Williamson DG, O'Donnell VJ 1969 The interaction of metopirone with adrenal mitochondrial cytochrome P-450. A mechanism for the inhibition of adrenal steroid 11 $\beta$-hydroxylation. Biochem 8:1306-1311

37. Capdevila J, Marnett LJ, Chacos N, Prough RA, Estabrook RW 1982 Cytochrome P-450-dependent oxygenation of arachidonic acid to hydroxyicosatetraenoic acids. Proc Natl Acad Sci USA 79:767-770 